https://helda.helsinki.fi

\title{
Instructional Theories of Exploratory Production
}

\section{Metsärinne, Mika}

2017

Metsärinne , M \& Kallio , M 2017 , ' Instructional Theories of Exploratory Production ' , Australasian journal of technology education, vol. 4 . https://doi.org/10.15663/ajte.v4i1.49

http://hdl.handle.net/10138/230817

https://doi.org/10.15663/ajte.v4i1.49

unspecified

publishedVersion

Downloaded from Helda, University of Helsinki institutional repository.

This is an electronic reprint of the original article.

This reprint may differ from the original in pagination and typographic detail.

Please cite the original version. 


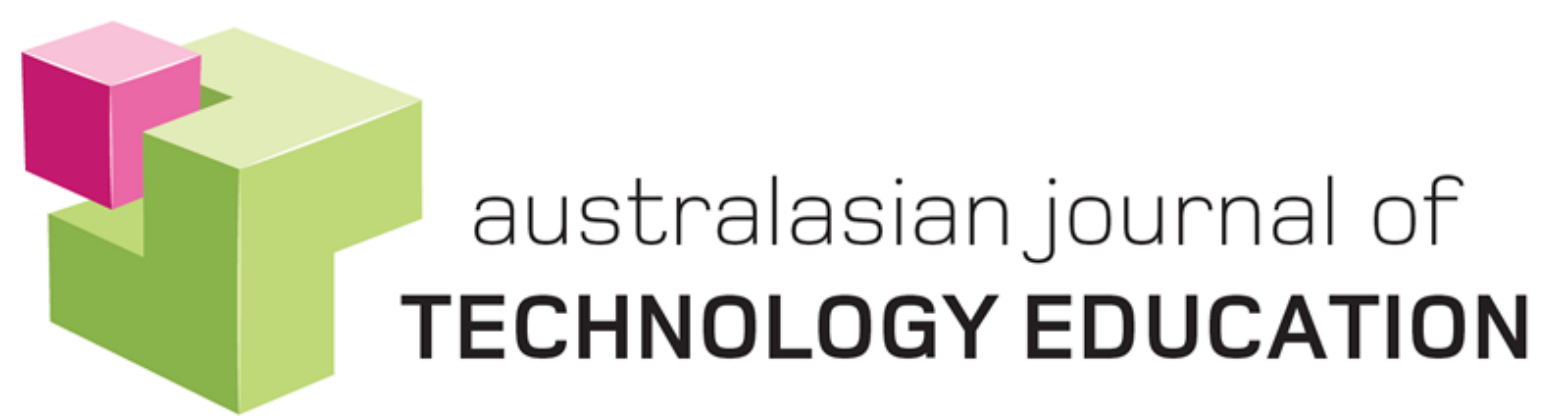

Editor: Professor P John Williams, Curtin University, Australia

Consulting Editor : Professor Alister Jones, University of Waikato, New Zealand

Editorial board:

Prof Jacques Ginestié, Aix-Marseille Université, France

Prof Stephanie Atkinson, Sunderland University, England

Prof Frank Banks, The Open University, England

AProf Howard Middleton, Griffith University, Australia

Dr Gary O'Sullivan, Massey University, New Zealand

Prof John Ritz, Old Dominion University, USA

Prof Lung-Sheng Steven Lee, National Taiwan Normal University

Prof Marc de Vries, Delft University of Technology, Netherlands

Dr Wendy Fox-Turnbull, University of Canterbury, New Zealand

The Australasian Journal of TechnologyEducation is a peer refereed journal, and provides a forum for scholarly discussion on topics relating to technology education. Submissions are welcomed relating to the primary, secondary and higher education sectors, initial teacher education and continuous professional development, and general research about Technology Education.

Contributions to the on-going research debate are encouraged from any country. The expectation is that the Journal will publish articles at the leading edge of development of the subject area.

The Journal seeks to publish

- reports of research,

- articles based on action research by practitioners,

- literature reviews, and

- book reviews.

Publisher: The Technology, Environmental, Mathematics and Science (TEMS) Education Research Centre, which is part of the Faculty of Education, The University of Waikato, publishes the journal.

Contact details: The Editor, AJTE, pjohn.williams@curtin.edu.au

Cover Design: Roger Joyce

This journal provides immediate open access to its content on the principle that making research freely available to the public supports a greater global exchange of knowledge.

ISSN: 2382-2007 


\title{
australasian journal of
TECHNOLOGY EDUCATION
}

\section{Instructional Theories of Exploratory Production}

Mika Metsärinne

Manne Kallio

\begin{abstract}
This research examines how the instructional theories of the exploratory production model are used in technology education. The data was gathered in the teacher training practice period during master's level teacher training in technology education. The four most learner-centred instructional theories are described and examples from the teacher practice provided. The empirical descriptions are based on the student teacher portfolios and the supervisor interviews. The cases reveal that the more open the learner-centred instructions the student teacher uses, the more multifaceted the learning is. Also, the learning is more intrinsically motivated and thereby deeper as regards the learners' own life-world. Varying between the different instructions helps student teachers to organize their classroom techniques and motivate learners through meaningful learning and collaboration. The instructional theories are applicable in differentiating teaching and learning between groups and between the learners within a particular group.
\end{abstract}

Keywords: Exploratory production, instructional theory, technology teacher training

\section{Introduction}

The research reported in this article examines how the instructional theories (Metsärinne, 2007) of the exploratory production model (EPM) were comprehended and used in teaching practice at the master's level of technology teacher education. The EPM concentrates on learner's technological production activities (cf. Peltonen, 2003). Learner's innovativeness and selfdirectedness is taught following the exploratory production model (Metsärinne, Kallio \& Virta, 2015; Kallio \& Metsärinne, 2017; comp. Zimmerman 1998, 4; 2011, 56). Exploratory production has a philosophical basis that includes both an existential (Heidegger, 1967) and a situational viewpoint (Dewey, 2012, 118-126). Learners are taught to set goals for their learning and to monitor, regulate and control their cognition, motivation and behaviour, guided and constrained by their goals and the contextual features of the environment. Each learning task with a unique production case renews the learner's knowledge base, which has an effect on the next task and case (Kallio \& Metsärinne, 2017). The instructional theories are examined in earlier articles (see Metsärinne et al., 2015; Kallio \& Metsärinne, 2017).

Four of the most Learner-Centred instructional theories consist of the three main phases in EPM: definition, implementation, and reliability and quality control. In the definition phase of the EPM, a learner defines goals for forthcoming technological production activities. The implementation 
phase that follows is regulated by the quality goals set in the definition phase. The profile of the quality preconditions for the implementation (ideation, planning and manufacturing) are defined in the definition phase. The reliability and quality control phase includes testing the goals set for the production and qualities of the product, assessing learning outcomes, and self-evaluation. Returning paths are addressed according to the goals defined for the entire production activity. Testing the novel technological product is linked to testing the quality profile of learning through the entire production activity. As the product indicates case-specific qualities, the learning outcomes indicate the individual growth of the learner's technological capability. This study focuses on envision, project, problem-based and process instructions. However, the model and traditional instructions are briefly described in the following summary.

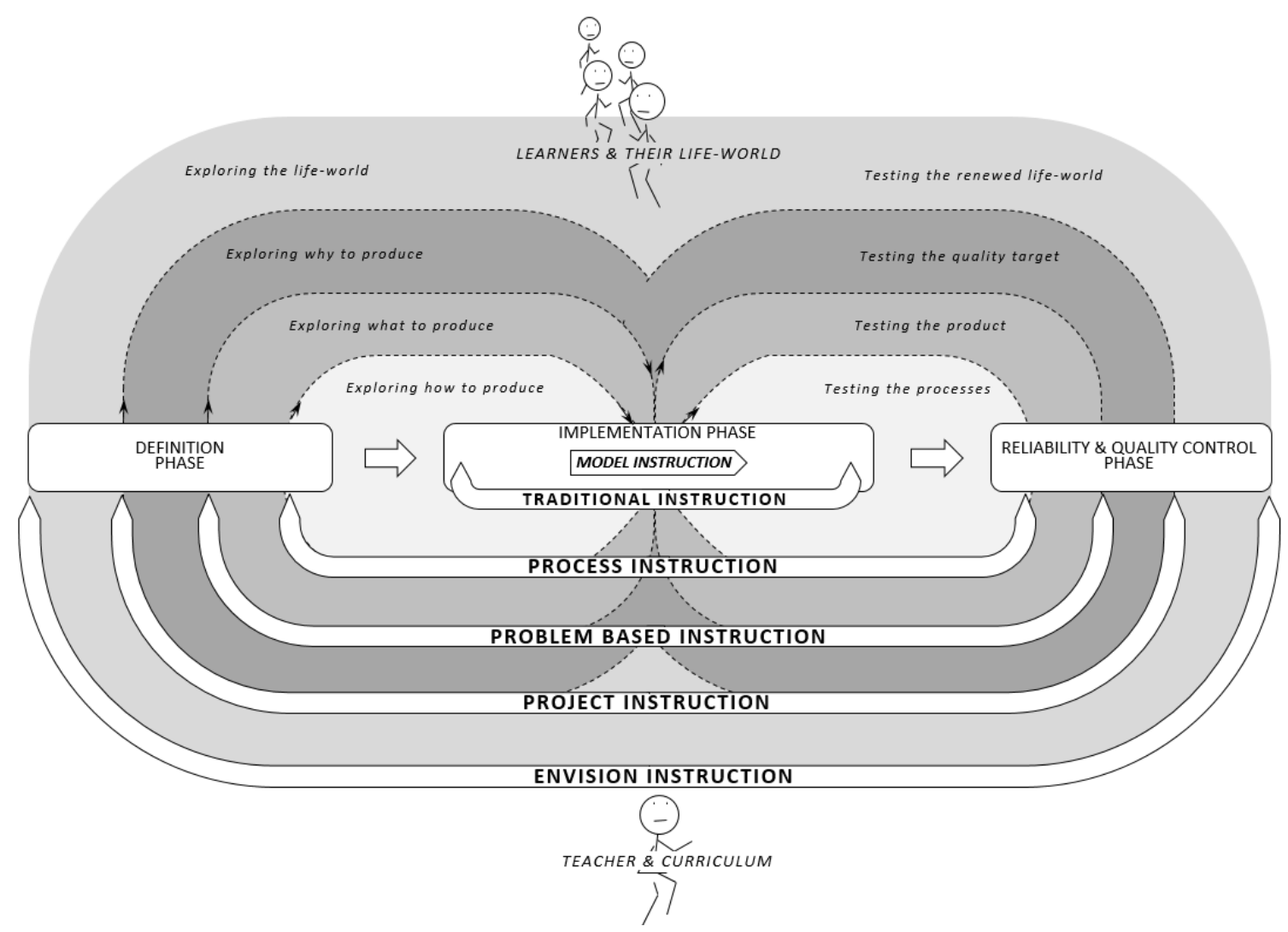

Figure 1. The instructional theories of the exploratory production model (EPM)

The integrated model of exploratory production and the instructional theories combine the extensions of production activities and learning in Figure 1. These theories have a basis in educational philosophies adapted from Wiles and Bondi (2002): envision instructions and existentialism; project constructions and experimentalism, 3) problem-based instructions and realism; process instructions and idealism; traditional instructions and idealism and perennialism; and model instructions and perennialism. Following a particular instructional theory allows the teacher to differentiate the instructions between the groups and between learners within a group. 
Following a particular educational philosophy is conveyed in the way a teacher applies the instructional theories to support the learner's technological awareness and the potential for learning and producing new technologies.

Educational perennialism is the most traditional background philosophy. Perennialist teachers instruct pupils in constructing artefacts or technological systems with closed learning tasks following the theory of model instructions. Perennialist teachers believe that human education is relatively constant. Nowadays, pupils seldom need to make such craft based artefacts for their everyday lives. However, they need aesthetic and technological knowledge and skills when they are using, repairing and programming all kinds of technologies. In these actions, they need to understand the internal structures of the technology. Model learning means acquiring technological knowledge and instructions on using certain technologies or techniques. It might mean constructing a particular technology or putting a predefined design process into practice.

\section{EDUCATIONAL PHILOSOPHIES}

\begin{tabular}{|c|c|c|c|c|c|c|}
\hline \multicolumn{7}{|l|}{ Existentialism } \\
\hline \multicolumn{7}{|l|}{ Realism } \\
\hline \multicolumn{7}{|l|}{ Idealism } \\
\hline \multirow{2}{*}{\multicolumn{7}{|c|}{$\begin{array}{l}\text { Perennialism / } \\
\text { Idealism }\end{array}$}} \\
\hline & & & & & & \\
\hline & $\begin{array}{l}\text { Model } \\
\text { Instructions }\end{array}$ & $\begin{array}{l}\text { Traditional } \\
\text { Instructions }\end{array}$ & $\begin{array}{l}\text { Process } \\
\text { Instructions }\end{array}$ & $\begin{array}{l}\text { Problem- } \\
\text { based } \\
\text { Instructions }\end{array}$ & $\begin{array}{l}\text { Project } \\
\text { Instructions }\end{array}$ & $\begin{array}{l}\text { Envision } \\
\text { Instructions }\end{array}$ \\
\hline
\end{tabular}

\section{INSTRUCTIONAL THEORIES}

Figure 2. The relation between the instructional theories of the EPM and the educational philosophies.

Educational idealism is related to traditional goals and content. An idealist teacher believes that there is an optimal learning task for each age group to learn certain technological knowledge and processes. The educational idealist follows and continues the tradition of developing standards for technological learning. When learners begin constructing their own solutions and processes, the traditional instructions turn to more open process instructions. While traditional instructions consist of detailed descriptions of how to plan and manufacture a product, process instructions consist of more general information about drawing and manufacturing, and the learner might follow their own ideas instead of following the ideas of the teacher. However, the process 
instructions consist of a quality profile for technological learning and production predefined by a teacher, while in higher instructional theories the quality profile is defined more by the learner. However, the process instructions allow the learner to define some personal goals as well as to implement the technological activities while the teacher instructs the learner in exploring and applying the technological knowledge of the content and processes. Since the selection of technologies, techniques and materials is more limited, the learning and production are directed towards particular objectives. The learner still has some decisions to make and problems to solve during the design and construction process.

Educational realism rests on the scientific knowledge and the power of science in solving the problems of the technological world. The realist teacher puts scientific theories into practice using problem-based learning in which the learners are expected to apply scientific knowledge in a practical case. Problem-based instructions consist of a problem related to the forthcoming technological production activities. Solving the problem is a case of the production of problembased instructions; however, there are many minor problems to solve all the way through any technological production activity (Metsärinne 2003a). Unlike in envision instructions and project instructions, the problem is set by the teacher instead of the learner being expected to define the problem by him/herself. The learning task is therefore more limited, and the learning and production are directed more by the teacher. The teacher guides the learner to explore problemsolving methods as well as analogies to other relevant problems in order to find a technological solution. The quality profile of the learning and production is already predefined for the most part. Hence, the learner is able to proceed to the ideation of the solution in the implementation phase quite soon.

Educational experimentalism, unlike perennialism, idealism or realism, is a philosophy of everchanging reality. Experimentalists constantly discover new ways to expand and improve the environment and society with technologies. For an experimentalist, technology is a project in the ever-changing entity of products, systems and development. Adopting the classification of Kilpatrick (1918), the projects are intentional productive processes with anticipated goals; that is to say, new technologies are produced intentionally in the technology education projects. Exploratory production as a procedure is comparable to the project method as it consists of goalsetting, designing, implementing and evaluating the outcomes (Metsärinne, 2004). Unlike envision instructions, in which the learners set the goals completely on their own, the project instructions consist of a theme predefined by the teacher; however, the theme must not refer to existing products or techniques. The teacher instructs the learner in exploring technological knowledge in order to define the quality profile for the production and learning. In addition, the teacher supports the learner in the product ideation, design and construction during the implementation phase.

Educational existentialism denotes the relativity of the world. The existentialist believes that everyone has their own perception of reality. This means that there are no universal qualities for technologies, all the qualities are case sensitive. The existentialist teacher believes in the abilities of learners to envision the potential and risk of the technological world. An existentialist teacher instructs the learners to envision their life-world to set goals for their learning, and monitor, regulate and control their cognition, motivation and behaviour, guided and constrained by their goals and the contextual features of the environment (Metsärinne \& Kallio, 2011; Metsärinne et al., 2015; Kallio, 2014). Envision instructions allow the learners to define the goals for their production activities individually. Thus the regulatory knowledge, on which the ideation, designing and constructing of the product are based, is entirely the learner's own. In the definition 
phase, the teacher's role is to stimulate the learner's thinking in exploring the values and risks of their life-world in order to enhance it. The learner is expected to answer why she/he is undertaking the forthcoming technological production activities and learning. During the implementation phase, the teacher supports the learner in examining the content and processes.

The research question was "How did the student teachers argue and apply the instructional theories of the EPM during their teacher practice period?"

\section{Method}

The use of instructional theories was examined during the final teacher practice period of the master's programme of technology education teacher training. In Finland, where the study took place, all teachers in compulsory and secondary education must have a master's degree. During the practice period, the student teachers are expected to construct their own usage theory for their teaching. They are acting as researchers, reflecting the practice against the theories of learning and instruction of technology education. At the beginning of the practice period, the student teachers compose the learning task for the pupils following the National Core Curriculum and local curricula and reflecting the educational theories. The student teachers are expected to apply the instructional theories, the models of technological production activities, and the theories of the interaction between the teacher and the learners in order to extend their research skills.

The students have three teaching practice periods altogether in different classes during their bachelor-level and master's-level studies. This training period took place in grade 8 and 9 classes in compulsory schools. Before the training period, students had to plan their own learning task, theoretical overview and lesson plans and present them with a university lecturer and the technology teacher in the school where the training was to take place. Technology teachers in schools had organized their own teaching processes so that student teachers were able to start their own teaching plans as soon as the first teaching hour began. The trainees' instructions for their portfolios state that at the end of the training period the trainee must assess each pupil of the group. Also, each pupil presents a self-evaluation which the student teacher evaluates and places in the portfolio. This study concerns the pedagogical learning instruction issues related to the exploratory production model.

The data consists of randomly selected student teacher portfolios $(n=100)$ of master's-level teacher training practice (years 2008-2013) in grade 8 and 9 technology education. The instructions for the student teacher portfolios state "at the end of the training period, the trainee must assess each pupil of the group ...[and]... a pupil presents self-evaluation."

The data was classified using theoretical content analysis based on the pedagogical theories of the exploratory production model. The data was classified and divided into the theoretical categories according to the descriptions of the instructional learning tasks. The classification indicator was the openness of each learning task. First two researchers did this independently. To ensure the reliability of the categorizations by the researchers, they were compared to each other. They had classified eight learning tasks in different ways. After that, a third researcher classified these tasks independently. The three researchers then discussed them and reached coherent decisions. For example 'You should create a bicycle rack' was not classified in the same way. One researcher thought it was a problem to transfer some goods. He had classified it in a group of problem-based learning tasks. Another researcher had classified it in group of process learning tasks, because the rack had been already named. When three researchers discussed this, they noticed that the task links directly to product planning and constructing. Instead of that, 'Transporting a thing with a 
bicycle' is a problem-based learning task in the next table, because the task is not included in what the product should be; for example, it also could be a trailer or backpack.

Table 1. The examples of the technological learning tasks.

\begin{tabular}{|c|c|c|}
\hline Instructional Theory & Cases $(\mathrm{N})$ & Examples of the Learning Tasks \\
\hline Envision instructions & 12 & $\begin{array}{l}\text { 'Produce a technological product to } \\
\text { enhance } \\
\text { the environment of life' }\end{array}$ \\
\hline Project instructions & 29 & $\begin{array}{l}\text { 'Cultural heritage' } \\
\text { 'Local cultural heritage' } \\
\text { 'Technology as a hobby' }\end{array}$ \\
\hline $\begin{array}{l}\text { Problem-based } \\
\text { instructions }\end{array}$ & 31 & $\begin{array}{l}\text { 'Transporting a thing with a bicycle' } \\
\text { 'Holding a particular thing' } \\
\text { 'Lifting a heavy object' }\end{array}$ \\
\hline Process instructions & 21 & $\begin{array}{l}\text { 'An electric vehicle' } \\
\text { 'Embedded electric control' } \\
\text { 'A particular musical instrument' }\end{array}$ \\
\hline $\begin{array}{l}\text { Traditional or Model } \\
\text { instructions }\end{array}$ & 7 & $\begin{array}{l}\text { 'Etching a copper plate' } \\
\text { 'Marquetry technique' } \\
\text { 'Servicing a bike or a moped' } \\
\text { 'A four-stroke engine' }\end{array}$ \\
\hline
\end{tabular}

The classification in Table 1 revealed that all of the instructional theories were used in the teacher practice. However, model instruction was used only in seven of one hundred cases. Model instructions were used in some teacher-directed cases in which the goal was acquiring very special technological knowledge or learning particular practices. On the other hand, learners also implemented very special technological solutions in the learner-centred cases when envision and project instructions were engaged in. The model and process instruction theories were used when the goal was to learn new technological content, while envision and project learning instructions were used when the goal was to explore solutions for more complicated production activities. The problem-based instructions were used when both learning and production was the preferred goal. Nevertheless, the more open the instructions used, the more thoughtful was the learning and the more complicated the production. Collaborative learning methods were used more when the project and problem-based instructions were applied, while more independent work was preferred when applying envision and process instructions. The relation between the learning task and the examples of the technologies reveal how multifaceted the learning is.

To answer the research question, one case from each class $(n=4)$, model and traditional learning instructions excluded, was selected for more detailed analysis to examine how the student teacher argued the use of the particular instructional theory and how the student teacher used the instructional theory during the training period. The descriptions were compared to feedback interviews from the supervisors. The student teacher's arguments reveal the technological learning task of the case and the general goals for learning. The established applications reveal the examples of technological production in each case. 


\section{Results}

The results of the analysis of the selected cases $(n=4)$ are shown using the student teachers' portfolios and supervisors reports (see Table 2). The descriptions in the portfolios are linked to the educational thinking informing the use of different kinds of instructions.

Table 2. Description of the selected cases $(n=4)$.

\begin{tabular}{|c|c|c|c|}
\hline $\begin{array}{l}\text { Learning } \\
\text { Instruction }\end{array}$ & General goals for learning & $\begin{array}{l}\text { Technological learning task } \\
(\mathrm{n}=4)\end{array}$ & $\begin{array}{c}\text { Examples of technological } \\
\text { production }(n=4)\end{array}$ \\
\hline \multirow{5}{*}{$\begin{array}{l}\text { \#1Envision } \\
\text { Instruction }\end{array}$} & Intrinsic motivation & \multirow{5}{*}{$\begin{array}{l}\text { Produce a technological } \\
\text { product to enhance the } \\
\text { environment of life' }\end{array}$} & An audio system for a \\
\hline & Attitudes & & moped-car \\
\hline & Self-regulated learning & & \multirow{2}{*}{$\begin{array}{l}\text { Thoughtful learning of } \\
\text { techniques or acquiring } \\
\text { technological knowledge }\end{array}$} \\
\hline & Self-assessment & & \\
\hline & Exploring the life-world & & $\begin{array}{l}\text { Furnishing and decorating } \\
\text { at home }\end{array}$ \\
\hline \multirow{4}{*}{$\begin{array}{l}\text { \#2 Project } \\
\text { Instruction }\end{array}$} & Innovativeness & \multirow{4}{*}{$\begin{array}{l}\text { 'A technology as a hobby' } \\
\text { The students were expected } \\
\text { to acquaint themselves with } \\
\text { the predefined theme. }\end{array}$} & \multirow{2}{*}{$\begin{array}{l}\text { Various holders and } \\
\text { carrying devices for sport }\end{array}$} \\
\hline & Exploring scientific & & \\
\hline & knowledge & & Different musical \\
\hline & $\begin{array}{l}\text { Developing technological } \\
\text { solutions }\end{array}$ & & \\
\hline \multirow{4}{*}{$\begin{array}{l}\text { \#3 Problem- } \\
\text { based } \\
\text { Instruction }\end{array}$} & Ideation & $\begin{array}{l}\text { 'A problem of lifting } \\
\text { objects' }\end{array}$ & \multirow[t]{4}{*}{$\begin{array}{l}\text { Various cranes and } \\
\text { elevators }\end{array}$} \\
\hline & Problem-solving & \multirow{3}{*}{$\begin{array}{l}\text { Students were expected to } \\
\text { explore a solution and } \\
\text { implement it in a miniature } \\
\text { model. }\end{array}$} & \\
\hline & Exploring phenomena & & \\
\hline & Mathematics and physics & & \\
\hline \multirow{3}{*}{$\begin{array}{l}\text { \#4 Process } \\
\text { Instruction }\end{array}$} & \multirow{2}{*}{$\begin{array}{l}\text { Acquiring technological } \\
\text { knowledge and learning } \\
\text { particular practices }\end{array}$} & 'A light or a lamp' & \multirow{3}{*}{$\begin{array}{l}\text { Various lights and lamps in } \\
\text { which predefined materials } \\
\text { or techniques were used }\end{array}$} \\
\hline & & \multirow{2}{*}{$\begin{array}{l}\text { The students learned the } \\
\text { principles and practice of } \\
\text { producing a circuit board } \\
\text { and CNC milling machine } \\
\text { based on the technology } \\
\text { implemented }\end{array}$} & \\
\hline & Design skills & & \\
\hline
\end{tabular}

\section{Case \#1: Envision instructions}

Student teacher \#1 explained his choice of the instructional theory using a three-step technology teaching model (Metsärinne, 2003b). According to the model, the grade 7 pupils are instructed mainly using the process learning instructions. The grade 8 pupils are encouraged to explore their own goals for their learning and technological production. The teacher gives the pupils a theme or a problem to solve using project- or problem-based instructions. The grade 9 pupils are expected to define their own goals for their technological production completely using envision learning. 
Student teacher \#1: The main feature in teachers' instructions is differentiating the learners' technological production. I do not see any reason to restrict the pupils' own intentions for their individual work. I can give alternative optional instructions for the pupils who are not able to work self-directively. In my opinion, it is easy to plan so-called closed learning tasks for those pupils who cannot define goals of their own. Technology education is an optional subject after $7^{\text {th }}$ grade. Thus, in the $8^{\text {th }}$ and $9^{\text {th }}$ grades the learning tasks should be open and learners should be able to express themselves and their interests from their own point of view. Moreover, I have realized that it is quite impossible to teach similar technological content to everyone as the diversity of the technological world has changed even during the time of my own course. I believe there is no ideal or universal technological future world to prepare pupils for, as everyone lives in their own life-worlds. Furthermore, in my opinion, a teacher cannot force a pupil to learn since, the pupils' motivation grows out of their own life situations and willingness to extend their knowledge of technologies. In my opinion, to achieve constant learning outcomes and awaken the pupils' life-long learning, the teacher's challenge is to instruct learners to find their own ways to expand their knowledge and grow into the technological world by themselves.

This student teacher paid special attention to awakening the intrinsic motivation and attitudes of learners in technological thinking and production activities by presenting learners with different sources of knowledge. He discussed this with each learner personally, as well as within small groups. The student teacher had time for this since no general syllabus or practices needed to be taught at the same time. As the learners' own goals were preferred, the assessment of the outcomes was easier. In the implementation phase, the assessment focused on the predefined quality profiles set by the learners themselves, not their technical performance. In the implementation phase, the student teacher used collaborative learning and instruction methods. The learning goals differed between the pupils within a group. The student and the supervising technology teacher were positively surprised at how well the entire class worked. The work was intensive, and collaboration was productive. The supervisor stated that the class worked more self-directively than usual, as the collaborative methods were used only when common learning tasks were applied to the entire group. One important notion was that the work of the pupils progressed through alternating periods of intensive work and presentations. After a period of ideation, planning or manufacture the pupils introduced to each other what they were doing. The pupils shared their ideas and knowledge with the entire class and everyone became aware of different viewpoints and the wide range of technologies being used and produced. At the end of the period, the newly-produced technologies were tested in the real use for which they were intended. This was, as expected, quite complicated as the technologies were for diverse purposes related to the pupils' leisure time activities, homes, and other areas.

\section{Case \#2: Project Instructions}

This student teacher argued that it is important to take pupils' previous knowledge, know-how and experiences of learning tasks and processes into account when planning instructions for learning.

Student teacher \#2: When I oriented myself in my teacher training period, I put questions to pupils of my training group. The pupils answered that they had experienced a lot of learning tasks related to electronics. They had produced for example a number of 
electronic devices with mechanical hardware recently, like those constructed using previous vacuum technology, i.e., using a lot of plastics. As the learning tasks had been in the limited area of technologies and materials using relatively closed learning tasks, I decided to instruct pupils to ideate the purpose of use for their forthcoming products at first. I wanted to orientate myself and learn how I could guide pupils to think about what technological products they need or what they want to produce for some other reason. Before teaching more detailed design methods, I used brainstorming methods to bring out diverse ideas. In my opinion, a teacher's role is to be a guide with plenty of ideas, but not give the pupils direct tips for about what kind of product they should produce. The teacher's role is to establish boundaries and set directions for the pupils' ideation to achieve relevant learning goals. The teacher presents pupils with a theme from which the project starts from with openended ideation.

Since all learners had the same theme, 'A technology as a hobby', the collaboration in small groups was fairly similar to what they had done earlier, but it was still productive. The learning task was not completely open, as the students were expected to acquaint themselves with the predefined theme. Since the student teacher instructed the learners to explore knowledge for their project theme, the pupils were able to go straight ahead and start composing the goals for their projects. The learners were expected to explore the theme thoughtfully before proceeding to the implementation phase and begin the ideation. The student teacher emphasized that a product sketch should not be ideated before the expected qualities for the forthcoming product and process were explored and defined. This was important in order to make the ideation meaningful and innovative, since beginning with a predefined product idea leads to a casual solution and underachievement. The learners, for example, compared their own criteria to those of other learners, as well as previous well-known solutions, and this also made the assessment more interesting in the end. Once the product ideation was under way, the trainee presented the learners with various possible techniques and technologies to increase their potential.

\section{Case \#3: Problem-based learning instructions}

Student teacher \#3 familiarised himself with technological knowledge and skills of his pupils in detail before his training period began, wanting to be aware of the kind of readiness they had. He was interested especially in what kind of technological problems they had solved in their lessons.

Student teacher \#3: In my first meeting with the pupils before my training period began, I found that pupils had planned and constructed very different kind of technological products at school. However the products had been for the pupils' own use in leisure time activities or homes, but not for solving any so-called real world problems. In my opinion, a general feature of technology education is in solving real world outof-classroom problems, such as practical solutions for physical phenomena. General education instructs the learner to understand technologies and plan new technologies to solve the problems of technologies. As a teacher, I choose a problem for the pupils, in which they also have to explore knowledge from other subjects. The products are actually models representing a real scale technological products, prototypes of a kind.

The first lesson began by presenting the learners with a problem for which a technological solution was expected. Since the problem was to lift objects, it was related to mathematics and physics. In small groups, the learners were directed to explore knowledge collaboratively about such things 
as transmissions, pneumatics, hydraulics, pulley tackles and the strength of constructions. Since the quality profile of the solution was predefined, the learners were able to proceed quite quickly to the ideation of the solution. The assessment focused on comparing the predefined quality profile to the test results of the solution such as a crane constructed by the learners. This kind of assessment seemed to motivate the learners because it was clearly comparable between the groups; however, the situation made the groups compete with one another.

\section{Case \#4: Process learning instructions}

The pedagogical thinking of student teacher \#4 led directly to certain technologies and processes for pupils to learn.

Student teacher \#4: Before this training period I checked out ITEA's standards for technological literacy again and I'm missing the same kind of instruction for Finland as well. In my opinion the constructed world and its several elements involves so much knowledge that it is difficult to concentrate on anything. It is not an easy task for a teacher to choose the technologies to teach in schools. One of the teacher's main tasks is to provide information for learning processes which the pupils are able to manage. I will not, however, exclude giving more open instructions for pupils if they are ready for them when I graduate as a teacher. When I observed my training class before my trainee period I noticed that these $8^{\text {th }}$ grade pupils cannot yet define realistic goals for learning and producing meaningful technological products.

Adopting technological knowledge and learning technological practices were highlighted in using process instructions. The student teacher presented the learners with more closed learning tasks with a clear character, such as a light or a lamp. The learners were expected to design and construct their solutions primarily using specified techniques and materials. The students learned the principles and practice of producing a circuit board and CNC milling machine based on the technology implemented. Even though the learners followed particular technological processes and used similar electric components, the design of the lamps varied widely. More systematic progress during the process was easier for learners who felt it was difficult to ideate and explore new areas of interest and knowledge. Unlike the higher learning theories, the focus of the assessment was more on the procedural matters than on self-regulated learning or innovativeness.

\section{Discussion}

Moving between the various instructional theories helps student teachers to organize the classroom techniques and motivate learners in meaningful learning and collaboration. The instructional theories are applicable in differentiating teaching and learning between different groups and between the learners within certain groups. In some cases, the student teachers used different instructions for some of the learners within a particular group. While most learners followed project instructions, some learners with difficulties in interaction skills, concentration, or attitudes, for instance, were given process instructions or even a model instruction. In addition, when a problem-based instruction was followed, for example, some learners with strong intrinsic motivation were allowed to envision their own technological production activities.

The instructional theories of the exploratory production model were used in a flexible way. Envision instructions were not used as often as the other instructions, and model and traditional instructions were used only rarely. The portfolios revealed that the student teachers using higher instructional theories presented more educational consideration, while those using traditional or 
model instructions presented more technical and practical consideration. These are the two ultimately contradistinctive theoretical approaches to learning and instruction. Envision instructions challenge learners to regulate their unique goals for the entire technological learning process and production activities, while model and traditional instructions generate more extrinsically motivated instrumental learning. As the use of envision or project learning challenges the student teacher in more theoretical thinking, the pupils' thinking is challenged to orientate the same way as well. Envision learning is more intrinsically motivated and selfregulated, the focus being on the goals set by the learner. Envision learning is based on the phenomena of the learner's own life-world and its enhancement by technological production activities. The learning of technological processes or content might remain more narrow but is nonetheless thoughtful. However, as the learners are expected to be more responsible for their learning and production when following the more open instructions, some learners might become frustrated. When moving to more open instructions, the role of the learner changes, step by step, from being a receiver of the teacher's guidance to being a self-directed explorer of her/his own technological production activities.

The emphasis on learner-centred technological production activities differs between cultures and over time. The twenty-first century conception of learning and instruction emphasizes learnercentred exploration and learning represents enhancement of the life-world rather than teacherdirected illustrations of scientific phenomena. However, knowledge of the laws of nature and principles of technologies are needed in exploratory production learning. When applying more learner-centred instructional theories, both teacher and pupils need to be aware of the risks and the potential of technologies, while when following teacher directed instructions, the risks are carried by the teacher, completely. In learner-centred instructions, the pupils are challenged to explore the environment of their lives and enhance it with technology, hence the learner faces the risks of his/her own technological production (cf. Kallio \& Metsärinne, 2016).

The problem of teaching technological production activities, however, is that whilst there is very good reason to draw up a list of qualities that are important in design and technology education, such lists tend towards atomization rather than holism (Kimbell, 2009, p. 5). The learning tasks designed by the teachers are thus not enough for thoughtful technological thinking by learners. Although such learning tasks might be related to interesting scientific phenomena with important technological content of STEAM subjects, for example, they might not relate to the life-world phenomena of the learner's real personal risks and potential. Such motivation is required in meaningful exploratory production activities.

The conclusion is that the goals of learning and production should be balanced using both learnercentred instructions and teacher-directed instructions. Finally, the learner's imagination represents the real life-world while the visual presentation of the teacher is an image. The utilities of the learner-centred goals and the general goals are combined in the instructional theories of the exploratory production model. All of the instructional theories are required in implementing the envision learning of the exploratory production model.

\section{Affiliations}

Mika Metsärinne

Adjunct Professor,

University of Turku, Finland

mikmet@utu.fi 
Manne Kallio

Lecturer,

University of Helsinki, Finland

manne.kallio@Helsinki.fi

\section{References}

Dewey, J. (2012). Filosofian uudistaminen (orig. Reconstruction in Philosophy, first published in 1920). Tampere, Finland: Vastapaino.

Heidegger, M. (1967). Sein und zeit. Tübingen, Germany: Max Niemeyer Verlag.

Kallio, M. (2014). Riskivastuullisuus turvallisuuskasvatuksen kulttuurissa. Oppilaiden vastuullisuus, turvallisuustaju ja tuottamistoiminnan riskiraja peruskoulun käsityön opetuksessa. (Risk-responsibility in safety education culture). Annales Universitatis Turkuensis C382. Turku, Finland: University of Turku.

Kallio, M. \& Metsärinne, M. (2016). Learners' conceptions of techno-risk tolerance. In J. de Vries, A. Bekker-Holtland \& G. van Dijk (Eds.). PATT-32 Proceedings. Technology Education for the $21^{\text {st }}$ Century skills (pp. 242-250). Retrieved from https://www.iteea.org/File.aspx?id=39504\&v=76e4030.

Kallio, M., \& Metsärinne, M. (2017). How do different background variables predict learning outcomes? International Journal of Technology and Design Education, 27(1), 31-50.

Kilpatrick, W. H. (1918). The project method. Teachers College Record, (XIX)4, 319-335.

Kimbell, R. (2009). Holism and the challenge of teachers' judgement. Design and Technology Education: An International Journal 14(1), 5-6.

Metsärinne, M. (2003a). Problem finding and problem solving in Sloyd. In K. Virta (Ed.). Current research on Sloyd Education. Techne Series A 5, 45-62.

Metsärinne, M. (2003b). Teknisen käsityön visio-opetus ja-oppiminen. Toiminta- ja tapaustutkimus peruskoulun 9. luokalla. (Sloyd vision teaching and learning. Case and action research on the 9th grade). Annales Universitatis Turkuensis C 198. Turku, Finland: University of Turku.

Metsärinne, M. (2004). Projektikäsityöopetus. Tapaustutkimus projektikäsityöhön ohjaavista opetusmuodoista sekä projektikäsityöopetuksen suunnittelun ja ohjaamisen perusteista. (Sloyd Project Teaching and Teaching Methods of Project Sloyd: Three Case Studies). Techne Series, A 6, 1-250.

Metsärinne, M. (2007). Käsityön oppimisen innovointi. (Sloyd learning innovation). In M. Metsärinne, \& J. Peltonen, (Eds.). Katosiko tekninen työ Turun yliopistosta? \& Käsityön oppimisen innovointi. Techne Series, A 11, 81-186.

Metsärinne, M. \& Kallio, M. (2011). Johdatus tutkivaan tuottamiseen. (Introduction into research-based production). Techne Series, B 16, 1-112.

Metsärinne, M. \& Kallio, M. (2015). How are student's attitudes related to their learning outcomes? International Journal of Technology and Design Education 26(3), 353-371.

Metsärinne, M., Kallio, M., \& Virta, K. (2015). Pupils' readiness for self-regulated learning in the forethought phase of exploratory production. International Journal of Technology and Design Education, 25(1), 85-108.

Peltonen, J. (2003). The chain of rational theories as the directing means of productive activities in academic Sloyd Education. In K. Virta (Ed.). Current research on Sloyd Education. Techne Series, A 5, 78-96. 
Zimmerman, B. J. (1998). Developing self-fulfilling cycles of academic regulation: An analysis of exemplary instructional models. In D. H. Schunk \& B. J. Zimmerman (Eds.). Selfregulated learning from teaching to self-reflective practice. (pp. 1-19) New York, NY: Guilford.

Zimmerman, B. J. (2011). Motivational sources and outcomes of self-regulated learning and performance. In: B. J. Zimmerman \& D. H. Schunk (Eds.) Handbook of self-regulation of learning and performance. (pp. 49-64). New York, NY: Routledge.

Wiles, J., \& Bondi, J. (2002). Curriculum development: A guide to practice (6th ed.). Upper Saddle River, NJ: Merrill Prentice Hall. 